\title{
How Does Green Credit Policy Affect Total Factor Productivity at the Corporate Level in China: The Mediating Role of Debt Financing and the Moderating Role of Financial Mismatch
}

\author{
Yanchao Feng \\ Zhengzhou University https://orcid.org/0000-0002-8240-0715 \\ Qiong Shen ( $\square$ shenqiong@zzu.edu.cn ) \\ Zhengzhou University
}

\section{Research Article}

Keywords: green credit policy, total factor productivity, debt financing, financial mismatch

Posted Date: October 22nd, 2021

DOI: https://doi.org/10.21203/rs.3.rs-996794/v1

License: (c) (1) This work is licensed under a Creative Commons Attribution 4.0 International License. Read Full License

Version of Record: A version of this preprint was published at Environmental Science and Pollution Research on November 20th, 2021. See the published version at https://doi.org/10.1007/s11356-02117521-3. 
How does green credit policy affect total factor productivity at the corporate level in China: The mediating role of debt financing and the moderating role of financial mismatch Yanchao Feng, Qiong Shen*

Business School, Zhengzhou University, Zhengzhou 450001, PR China

* Correspondence to shenqiong@zzu.edu.cn

Abstract: Taking the "Green Credit Guidelines" issued in 2012 as a quasi-natural experiment and employing the A-share listed enterprises scanning from 2008 to 2020 as the research sample, this study has investigated the impact of green credit policy on total factor productivity at the corporate level in China, with the consideration of the mediating role of debt financing and the moderating role of financial mismatch. The findings are as follows: (1) green credit policy has effectively and directly promoted total factor productivity at the corporate level in China; (2) the mediating role of debt financing is merely supported for the full sample and the state-owned sample; (3) the moderating role of financial mismatch is merely established via codirectionally moderating the negative impact of green credit policy on debt financing for the full sample and the eastern sample; (4) the non-state-owned enterprises' dilemma of difficult and expensive debt financing is proved. The conclusions and policy implementations are provided in the last section to highlight the practical and theoretical significance of this study.

Keywords: green credit policy; total factor productivity; debt financing; financial mismatch

\section{Introduction}

The concept of green credit comes from green finance, while green credit policy is a new credit policy to curb the blind expansion of energy-intensive and high pollution industries, which is initially proposed by State Environmental Protection Administration (SEPA), the People's Bank of China (PBOC), and the China Banking Regulatory Commission (CBRC) in 2007, while the implementation of this policy is poor due to inadequate supporting measures (Zhang et al., 2011; Sun et al., 2019). To the best of our knowledge, it's widely acknowledged that green credit policy is a macro-level regulation pattern to promote environmental protection by means of credit, which is one effective way for banking financial institutions to fulfill their environmental responsibilities (Liu et al., 2017). In addition, green credit brings environmental risk into credit management and 
strictly prevents credit funds from flowing into polluting industries (Zhang et al., 2011). Thus, the main essence of green credit policy is to find a trade-off between economic development and environment protection (Kang et al., 2020).

As an emerging economy, China's financial market is still in an imperfect environment, the bank-dominated financial system forms the main body of the financial sector (Cao et al., 2021). According to the "Green Credit Guidelines" issued in 2012, commercial banks should impose higher rates on heavy-pollution industries to limit loans to those industries (Han et al., 2019). Constrained by the imperfect financial market and the low information transparency, Chinese enterprises rely more on short-term loans because of its advantage in flexibility to support long-term investment (Cao et al., 2021). Thus, debt financing forms the key route to be considered in analyzing the impact of green credit policy (Liu et al., 2019; Xu ad Li, 2020). Against this background, taking the "Green Credit Guidelines" issued in 2012 as a quasi-natural experiment and treating the pollution-intensive enterprises as the treatment group, this study attempts to explore the impact of green credit policy on total factor productivity with the consideration of the mediating role of debt financing.

In addition, considering the real existence of financial market friction, unequal distribution of financial resources, and other phenomenon of financial mismatch, whether and how financial mismatch affects the nexus between green credit policy and total factor productivity becomes another incentive of this study (Moll, 2014; Wu, 2018). On one hand, financial mismatch usually leads to the inefficient utilization of financial resources and the chaos in the financial market, which is not conducive to the sustainable development of the economy (Uras, 2014). On the other hand, financial mismatch also to some extent represents the flexibility of the economy, which means more opportunity or lead to better economic performance (Karabarbounis and Macnamara, 2021). Therefore, this study also attempts to investigate the moderating role of financial mismatch on the nexus between green credit policy, debt financing, and total factor productivity.

Furthermore, considering the typical regional heterogeneity in China caused by the differences in economic foundations, resource endowments, and environmental conditions, this study attempts to divide the full sample into different regions in the process of empirical analysis (Wang et al., 2019). Last but not least, it's widely known that the state-owned enterprises are the dominant part of the socialist market economy with Chinese characteristic, while the 
non-state-owned enterprise has the disadvantage in enjoying the bonus of green credit policy, thus the property rights of enterprises should also not be ignored in empirical analysis (Liu et al., 2019; Ling et al., 2020; Cao et a., 2021; Wen et al., 2021). Therefore, with the consideration of both the mediating role of debt financing and the moderating role of financial mismatch, this study will investigate the impact of green credit policy on total factor productivity at national, regional, and property rights levels.

The marginal contributions of this study to the literature can be largely summarized as two points. First, taking the "Green Credit Guidelines" issued in 2012 as a quasi-natural experiment and treating the pollution-intensive enterprises as the treatment group, this study has initially explored the impact of green credit policy on total factor productivity, which is conducive for identifying the impact of green credit policy at the corporate level. Second, from the perspective of financial resource allocation, this study has revealed the influencing mechanism of green credit policy on total factor productivity with the consideration of both the mediating role of debt financing and the moderating role of financial mismatch, which provides a micro-level empirical reference for related studies.

The rest of this study is organized as follows. In section 2, we review the relevant literature and put forward research hypotheses. In section 3, we introduce the methodology and data employed in this paper. We present and analyze our empirical results in Section 4. Section 5 draws the conclusions, gives some policy implications, and points out the research prospects. The analysis procedure of this study is illustrated in Fig.1.

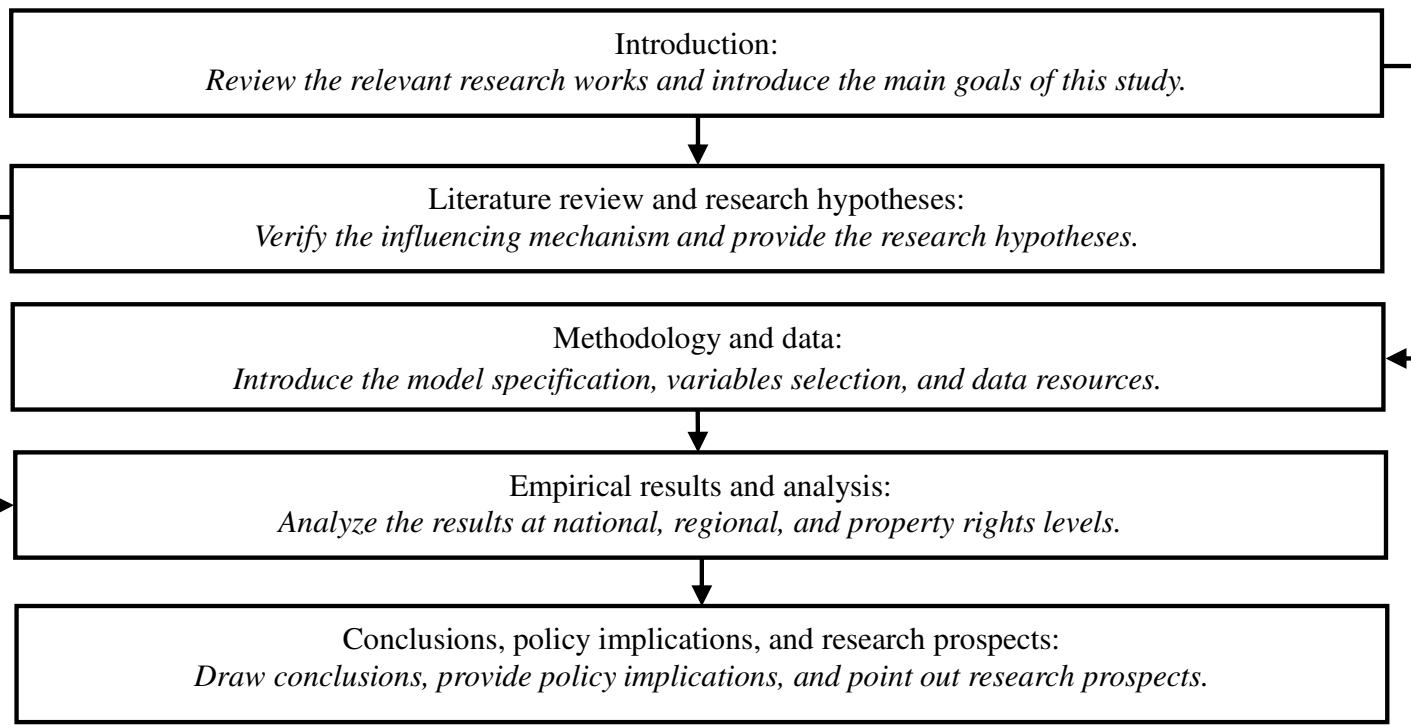

Fig. 1. Flow chart of the analysis procedure. 


\section{Literature review and research hypotheses}

\subsection{Green credit policy and total factor productivity}

In order to promote the harmony between ecological environment and economic development, green credit policy requires commercial banks and other financial institutions to assess the environmental risks of loan projects cautiously, increase the financial sector's preference for green projects, and strengthen the guiding role of social funds through the loan market (Wang et al., 2018; Hu et al., 2021). Against this background, providing more loans for environmental friendly or energy-saving enterprises and less loans for highly-polluting or energy-intensive enterprises will speed up the process of industrial structure upgrading by adopting advanced green production technology and adjusting the investment strategy, which is conducive for forcing or inspiring all enterprises to improve their total factor productivity in the long run (Ling et al., 2020; Song et al., 2021; Wen et al., 2021; Zhou et al., 2021). Thus, we propose the following hypothesis.

Hypothesis 1 (H1): Green credit policy has a positive effect on total factor productivity at the corporate level in China.

\subsection{The mediating role of debt financing}

In general, the heavily polluting enterprises usually have the advantage of political status, especially in the emerging country such as China (Ling et al., 2020). After the implementation of green credit policy, this initial advantage of heavily polluting enterprises no longer existed and was replaced by the strict regulation of government authorities (Cao et al., 2021; Wang et al., 2021). At the same time, commercial banks have to restrict loans to heavily polluting enterprises, especially long-term loans, that is, green credit policy has a negative effect on debt financing (Xiang et al., 2020). However, without the constraint of debt financing, heavily polluting enterprises have adequate liquidity to maintain operation and even expand scale, but lose the motivation to promote green transformation, which is not conducive for promoting total factor productivity of them (Wang and Zhu, 2017; Xu et al., 2020). If both the negative assumption of green credit policy on debt financing and the negative assumption of debt financing on total factor productivity are supported, debt financing has a positive mediating effect on the nexus between green credit policy and total factor productivity. Therefore, we propose the following hypotheses. 
Hypothesis 3 (H3): Debt financing has a partly positive mediating effect on the nexus between green credit policy and total factor productivity.

\subsection{The moderating role of financial mismatch}

If the financial allocation is balanced and effective, the free flow of labor, technology, and other economic resources helps to form a reasonable factor allocation structure, which is conducive for promoting the resource allocation efficiency and increasing the total factor productivity (Wen et al., 2021). However, China's financial market has the characteristics of immature and imperfect, while the non-market behaviors and institutional constrains will mislead the direction of capital flow (Cao et al., 2021). Hence, this study assumes that financial mismatch weakens the positive impact of green credit policy on total factor productivity via directly moderating the nexus between them.

Furthermore, the low efficiency of financial resource allocation caused by financial misallocation could enhance the impact of green credit policy on reducing debt financing, that is, financial mismatch enhances the positive impact of green credit policy on total factor productivity via codirectionally moderating the negative impact of green credit policy on debt financing ( $\mathrm{Wu}$, 2018). However, under the dual pressure of debt financing and financing mismatch, the enterprises have no choice but to conduct green transformation, which may in turn promote the total factor productivity of them, that is, financial mismatch weakens the positive impact of green credit policy on total factor productivity via oppositely moderating the negative impact of debt financing on total factor productivity (Uras, 2014). Based on the above discussion, we propose the following hypotheses.

Hypothesis 4 (H4): Financial mismatch weakens the positive impact of green credit policy on total factor productivity via directly moderating the nexus between them.

Hypothesis 5 (H5): Financial mismatch enhances the positive impact of green credit policy on total factor productivity via codirectionally moderating the negative impact of green credit policy on debt financing.

Hypothesis 6 (H6): Financial mismatch weakens the positive impact of green credit policy on total factor productivity via oppositely moderating the negative impact of debt financing on total factor productivity.

\subsection{The conceptual model of this study}



mediates the relation between green credit policy and total factor productivity (Fig.2). Secondly, we also examined the moderating effect of financial mismatch on the indirect (H5 and H6) and direct paths (H4) in this model.

159

160

161

162

163

164

165

166

167

168

169

170

171

172

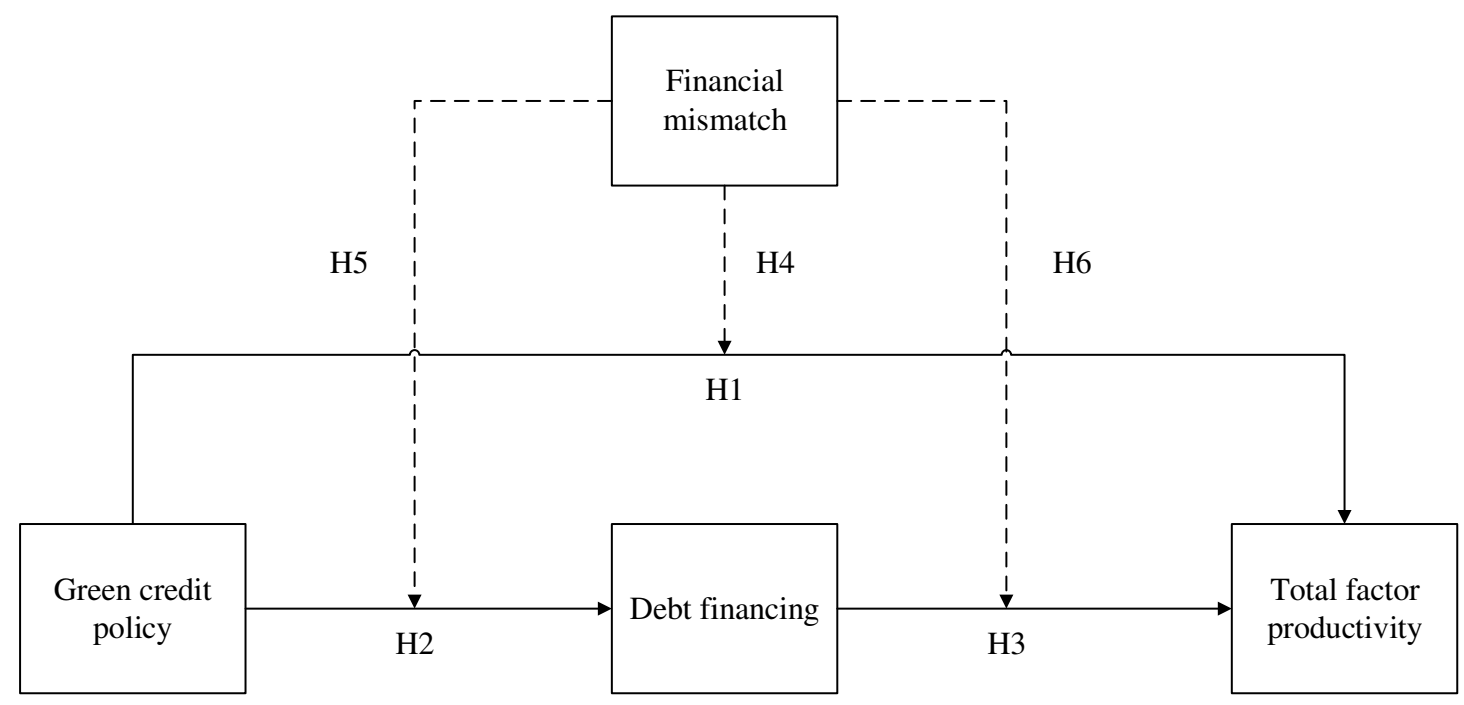

Fig.2. The conceptual mediated moderation model.

\section{Methodology and Data}

\subsection{Model specification}

The difference-in-differences model has been usually used in the quantitative evaluation of economic policies. To verify the hypotheses H1 to H6, following the models of Liu et al. (2019) and Wen et al. (2021), we set the econometric models as follows.

$$
\operatorname{TFP}_{i t}=\beta_{0}+\beta_{1} \times \text { Treat }_{i} \times \text { Post }_{t}+\beta_{2} \times \text { Controls }_{i t}+\varphi_{t}+\varepsilon_{i t}
$$

$$
D F_{i t}=\eta_{0}+\eta_{1} \times \text { Treat }_{i} \times \text { Post }_{t}+\eta_{2} \times \text { Controls }_{i t}+\varphi_{t}+\varepsilon_{i t}
$$

$$
\text { TFP }_{i t}=\tau_{0}+\tau_{1} \times \text { Treat }_{i} \times \text { Post }_{t}+\tau_{2} \times \text { DF }_{i t}+\tau_{3} \times \text { Controls }_{i t}+\varphi_{t}+\varepsilon_{i t}
$$

$+\pi_{4} \times$ Controls $_{i t}+\varphi_{t}+\varepsilon_{i t}$

$+\rho_{4} \times$ Controls $_{i t}+\varphi_{t}+\varepsilon_{i t}$ 
where $T F P_{i t}$ denotes the total factor productivity of firm $i$ in year $t$. Treat $t_{i}$ refers to the grouping dummy variable, which equals one if the firm $i$ belongs to the heavy pollution industry and zero otherwise. Post $t_{t}$ is the time dummy variable, which equals one after policy intervention and zero otherwise. $D F_{i t}$ denotes the debt financing of firm $i$ in year $t . F M_{i t}$ denotes the financial mismatch of firm $i$ in year $t$. Controls $s_{i t}$ refer to a vector of control variables. $\beta_{0}, \eta_{0}, \tau_{0}, \pi_{0}, \rho_{0}$, and $\lambda_{0}$ denote the coefficients of the constant term. $\beta_{1}, \beta_{2}, \eta_{1}, \eta_{2}, \tau_{1}, \tau_{2}, \tau_{3}, \pi_{1}, \pi_{2}, \pi_{3}, \pi_{4}, \rho_{1}, \rho_{2}, \rho_{3}, \rho_{4}, \lambda_{1}, \lambda_{2}, \lambda_{3}, \lambda_{4}$, and $\lambda_{5}$ denote the coefficients of the corresponding terms. $\varphi_{t}$ is the time fixed effect. $\varepsilon_{i t}$ refers to the residual.

As shown in Fig.2, $\beta_{1}$ is employed to measure the direct effect of green credit policy on total factor productivity, that is, to test the establishment of $\mathrm{H} 1 . \eta_{1}$ is employed to measure the direct effect of green credit policy on debt financing, that is, to test the establishment of $\mathrm{H} 2 . \eta_{1} \times \tau_{2}$ is employed to measure the indirect effect of green credit policy on total factor productivity or to measure the mediating effect of debt financing on the nexus between green credit policy and total factor productivity, that is, to test the establishment of H3. $\pi_{3}$ is employed to measure the moderating effect of financial mismatch on the nexus between green credit policy and total factor productivity, that is, to test the establishment of H4. $\rho_{3} \times \lambda_{4}$ is employed to measure the moderating effect of financial mismatch on the nexus between green credit policy and debt financing, that is, to test the establishment of H5. $\rho_{1} \times \lambda_{5}$ is employed to measure the moderating effect of financial mismatch on the nexus between debt financing and total factor productivity, that is, to test the establishment of H6.

\subsection{Variables selection}

(1) Dependent variable

Total factor productivity (TFP) is defined as the natural logarithm of the TFP, and TFP is estimated by referring to the study of Levinsohn and Petrin (2003).

(2) Core explanatory variables

Two dummy variables are employed to act as the proxy indicators of green credit policy, such as the group dummy variable (Treat) and the time dummy variable (Post). In particular, the group dummy variable (Treat) equals one if the enterprise belongs to the treatment group, and zero otherwise; the time dummy variable (Post); the group dummy variable (Treat) equals one after the implementation of the policy, and zero otherwise (Cao et al., 2021). 
(3) Mediating variable

Referred to the study of Wang et al. (2019), debt financing $(D F)$ is measured by the ratio of long-term loans to total assets.

(4) Moderating variable

Financial mismatch $(F M)$ refers to the departure degree of corporate capital cost to industrial capital cost, which is measured as follows.

$$
F M_{i t}=\frac{I_{i t} /\left(L_{i t}-A_{i t}\right)-R_{p t}}{R_{p t}}
$$

where $F M_{i t}$ denotes the financial mismatch of firm $i$ in year $t$. $R_{p t}$ denotes the average cost of industry $p$ in year $t . I_{i t}$ denotes the interest expenditure of firm $i$ in year $t . L_{i t}$ denotes the liability of firm $i$ in year $t . A_{i t}$ denotes the accounts parable of firm $i$ in year $t$.

(5) Control variables

Except for the key explanatory variables, the mediating variable, and the moderating variable, many other factors should be controlled when studying the impact of green credit policy on total factor productivity at the corporate level in China. Referring to the previous studies, the control variables included: (1) Age(Age), which is measured by the number of years from the issue period to the current period; (2) Size(Size), which is measured by the natural logarithm of the total assets; (3) Shareholding concentration $(S C)$, which is measured by the percentage of shares owned by the largest shareholder; (4) Leverage(Lev), which is measured by the ratio of total debt to total assets; (5) Return on assets $(R O A)$, which is measured by the ratio of net income to total assets; (6) Return on net assets $(R O E)$, which is measured by the ratio of net income to net assets; (7) Growth rate of total assets(GRTA), which is measured by the ratio of assets growth in current year to total assets at the beginning of the year.

\subsection{Data resources}

The panel data adopted in this study include the samples of the A-share listed enterprises selected from the Shanghai Stock Exchange and Shenzhen Stock Exchange scanning from 2008 to 2020, with polluting enterprises as the treatment group and the remaining enterprises as the control group by referring to the classification method of Ling et al. (2020). To guarantee the validity of the empirical results, the samples with the following characteristics are excluded: (1) enterprises with ST or ST* treated, (2) enterprises belong to the financial industry, (3) enterprises 
with serious missing variables. In addition, to exclude extreme outliers, we winsorize all continuous variables at the $1 \%$ and $99 \%$ quantiles annually. Finally, 15024 enterprise-year observations were obtained, including 5902 enterprise-year observations in the treatment group and 9122 enterprise-year observation in the control group. The corporate data of this study are collected from the China Stock Market and Accounting Research (CSMAR) database. The descriptive statistics of all variables are shown in Table 1.

Table 1

239 Descriptive statistics.

\begin{tabular}{llccccc}
\hline Attributes & Variables & $\mathrm{N}$ & Mean & Std.Dev. & Min & Max \\
\hline Dependent variable & TFP & 15024 & 10.980 & 1.195 & 7.330 & 14.964 \\
Key explanatory variables & Treat & 15024 & 0.393 & 0.488 & 0.000 & 1.000 \\
& Post & 15024 & 0.832 & 0.374 & 0.000 & 1.000 \\
Mediating variable & DF & 15024 & 0.055 & 0.074 & -0.123 & 0.846 \\
Moderating variable & FM & 15024 & -0.011 & 0.769 & -1.000 & 3.284 \\
Control variables & Age & 15024 & 2.181 & 0.629 & 1.099 & 3.367 \\
& Size & 15024 & 22.079 & 1.161 & 18.886 & 27.547 \\
& SC & 15024 & 33.857 & 14.165 & 2.870 & 89.990 \\
& LEV & 15024 & 0.415 & 0.193 & 0.007 & 1.114 \\
& ROA & 15024 & 0.037 & 0.074 & -1.648 & 0.786 \\
& ROE & 15024 & 0.026 & 0.972 & -66.535 & 2.324 \\
& GRTA & 15024 & 0.149 & 0.438 & -0.929 & 19.095 \\
\hline
\end{tabular}

\section{Empirical results and analysis}

\subsection{Correlation analysis and parallel trend test}

The Pearson correlation coefficients of between the independent variables including the key explanatory variables, the mediating variable, and the moderating variable are reported in Table 2. The highest correlation coefficient among them is 0.479 , implying that there is no serious multicollinearity. At the same time, we further conduct the variance inflation factor (VIF) test, and the highest VIF is 1.88 , thus the multicollinearity concern can be safely ignored once again.

The assumption of parallel trend should be satisfied for using the DID method, and the results are presented in Fig.3. Obviously, it basically satisfies the assumption of parallel trend, which meets the requirement for using the DID method. However, the coefficients of green credit policy do not become significant in statistic until five years later, indicating a five-year lag in the effect of green credit policy on total factor productivity at the corporate level in China. 


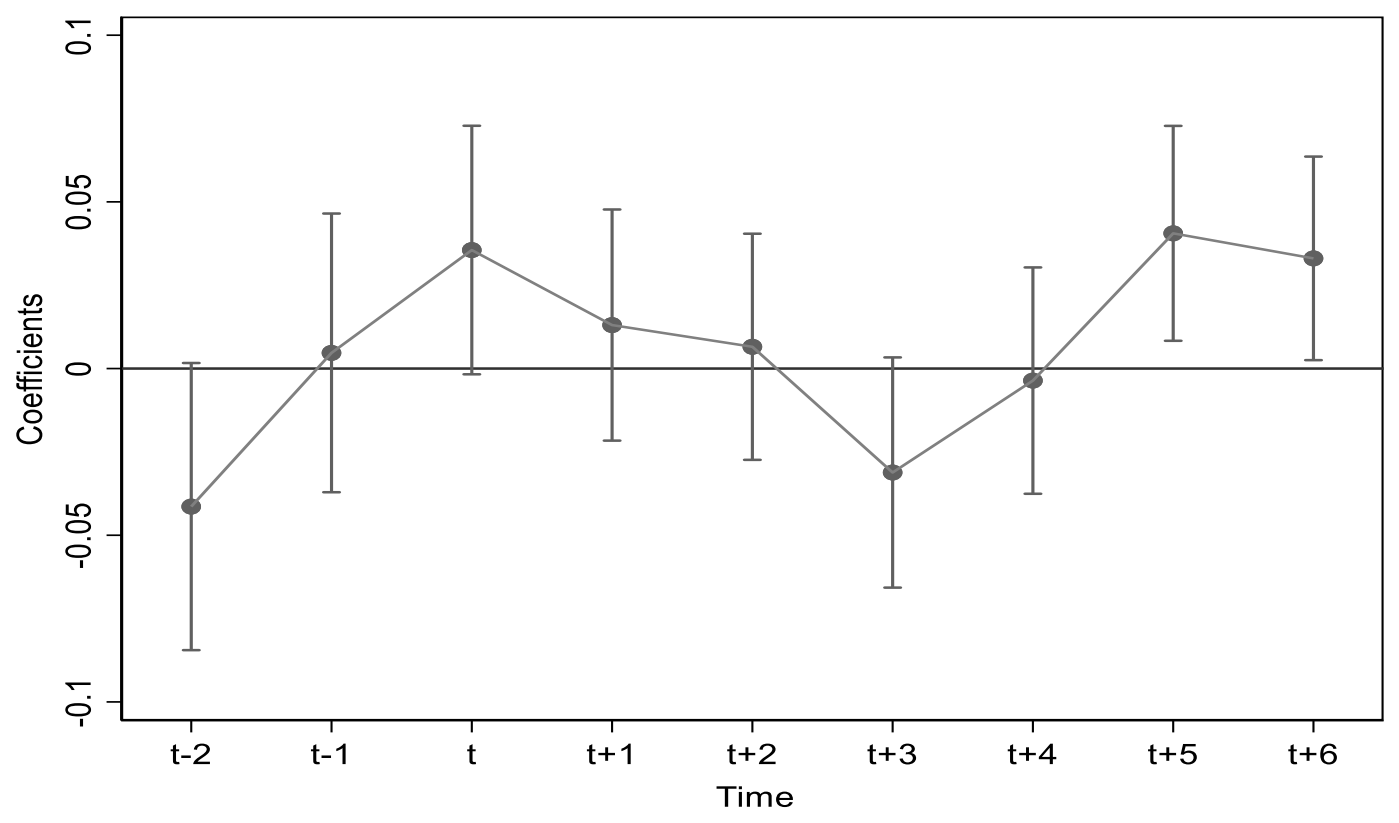

252

253

254

255 Correlation analysis.

Fig.3. Parallel trend test.

\begin{tabular}{|c|c|c|c|c|c|c|c|c|c|c|c|c|}
\hline $\begin{array}{l}\text { Varia } \\
\text { ble }\end{array}$ & $\begin{array}{l}\text { VI } \\
\text { F }\end{array}$ & Treat & Post & $D F$ & $F M$ & Age & Size & $O C$ & $S E V$ & $R O A$ & $R O E$ & $\begin{array}{l}\text { TAG } \\
R\end{array}$ \\
\hline Treat & $\begin{array}{r}1.0 \\
5\end{array}$ & 1 & & & & & & & & & & \\
\hline Post & $\begin{array}{r}1.1 \\
1\end{array}$ & $\begin{array}{l}-0.052 \\
* * *\end{array}$ & 1 & & & & & & & & & \\
\hline$D F$ & $\begin{array}{r}1.4 \\
0\end{array}$ & $\begin{array}{l}0.132 * \\
* *\end{array}$ & $\begin{array}{l}-0.056 \\
* * *\end{array}$ & 1 & & & & & & & & \\
\hline$F M$ & $\begin{array}{r}1.1 \\
9\end{array}$ & -0.008 & $\begin{array}{l}0.039 * \\
* *\end{array}$ & $\begin{array}{l}0.246 * \\
* *\end{array}$ & 1 & & & & & & & \\
\hline Age & $\begin{array}{r}1.3 \\
0\end{array}$ & $\begin{array}{l}0.115^{*} \\
* *\end{array}$ & -0.002 & $\begin{array}{l}0.164 * \\
* *\end{array}$ & $\begin{array}{l}0.115^{*} \\
* *\end{array}$ & 1 & & & & & & \\
\hline Size & $\begin{array}{r}1.6 \\
7\end{array}$ & $\begin{array}{l}0.074 * \\
* *\end{array}$ & $\begin{array}{l}0.104 * \\
* *\end{array}$ & $\begin{array}{l}0.352 * \\
* *\end{array}$ & $\begin{array}{l}0.082 * \\
* *\end{array}$ & $\begin{array}{l}0.396^{*} \\
* *\end{array}$ & 1 & & & & & \\
\hline$O C$ & $\begin{array}{r}1.0 \\
9\end{array}$ & $\begin{array}{l}0.034 * \\
* *\end{array}$ & $\begin{array}{l}-0.068 \\
* * *\end{array}$ & 0.005 & $\begin{array}{l}-0.116 \\
* * *\end{array}$ & $\begin{array}{l}-0.081 \\
* * *\end{array}$ & $\begin{array}{l}0.162 \\
* * *\end{array}$ & 1 & & & & \\
\hline$S E V$ & $\begin{array}{r}1.8 \\
8\end{array}$ & 0.002 & $\begin{array}{l}-0.152 \\
* * *\end{array}$ & $\begin{array}{l}0.479 * \\
* *\end{array}$ & $\begin{array}{l}0.308^{*} \\
* *\end{array}$ & $\begin{array}{l}0.314 * \\
* *\end{array}$ & $\begin{array}{l}0.451 \\
* * *\end{array}$ & $\begin{array}{l}0.046 \\
* * *\end{array}$ & 1 & & & \\
\hline$R O A$ & $\begin{array}{r}1.3 \\
5\end{array}$ & $\begin{array}{l}0.043 * \\
* *\end{array}$ & $\begin{array}{l}-0.031 \\
* * *\end{array}$ & $\begin{array}{l}-0.161 \\
* * *\end{array}$ & $\begin{array}{l}-0.268 \\
* * *\end{array}$ & $\begin{array}{l}-0.110 \\
* * *\end{array}$ & $\begin{array}{l}0.047 \\
* * *\end{array}$ & $\begin{array}{l}0.120 \\
* * *\end{array}$ & $\begin{array}{l}-0.323 \\
* * *\end{array}$ & 1 & & \\
\hline$R O E$ & $\begin{array}{r}1.0 \\
9\end{array}$ & $0.015^{*}$ & $\begin{array}{l}-0.014 \\
*\end{array}$ & $\begin{array}{l}-0.048 \\
* * *\end{array}$ & $\begin{array}{l}-0.075 \\
* * *\end{array}$ & $\begin{array}{l}-0.036 \\
* * *\end{array}$ & 0.006 & $\begin{array}{l}0.033 \\
* * *\end{array}$ & $\begin{array}{l}-0.117 \\
* * *\end{array}$ & $\begin{array}{l}0.278 \\
* * *\end{array}$ & 1 & \\
\hline $\begin{array}{l}T A G \\
R\end{array}$ & $\begin{array}{r}1.0 \\
5\end{array}$ & $\begin{array}{l}-0.017 \\
* *\end{array}$ & -0.013 & $\begin{array}{l}0.058^{*} \\
* *\end{array}$ & $\begin{array}{l}-0.092 \\
* * *\end{array}$ & $\begin{array}{l}-0.088 \\
* * *\end{array}$ & $\begin{array}{l}0.072 \\
* * *\end{array}$ & $\begin{array}{l}-0.015 \\
*\end{array}$ & $\begin{array}{l}0.018^{*} \\
*\end{array}$ & $\begin{array}{l}0.152 \\
* * *\end{array}$ & $\begin{array}{l}0.051 \\
* * *\end{array}$ & 1 \\
\hline
\end{tabular}




\subsection{Empirical results for the full sample and analysis}

Based on the equations (1) (6), this study has conducted the estimation and reported the empirical results for the full sample in the Table 3. Column (1) shows that green credit policy has significantly positive effect on total factor productivity, indicating that green credit policy promotes total factor productivity of the polluting enterprises, that is, $\mathrm{H} 1$ is supported for the full sample. Column (2) shows that green credit policy has significantly negative effect on debt financing, indicating that green credit policy reduces debt financing of the polluting enterprises, that is, $\mathrm{H} 2$ is supported for the full sample. Column (3) shows that debt financing has significantly negative effect on total factor productivity, indicating that debt financing has partly and positively mediated the nexus between green credit policy and total factor productivity, that is, H3 is supported for the full sample. Column (4) shows that financial mismatch has failed to moderate the positive effect of green credit policy on total factor productivity, that is, H4 is not supported for the full sample. Columns (5) and (6) show that financial mismatch has enhanced the positive impact of green credit policy on total factor productivity via codirectionally moderating the negative impact of green credit policy on debt financing, and weakened the positive impact of green credit policy on total factor productivity via oppositely moderating the negative impact of debt financing on total factor productivity, that is, both $\mathrm{H} 5$ and $\mathrm{H} 6$ are supported for the full sample.

\section{Table 3}

Empirical results for the full sample.

\begin{tabular}{lcccccc}
\hline Variables & $T F P$ & $D F$ & $T F P$ & $T F P$ & $D F$ & $T F P$ \\
\cline { 2 - 7 } & $(1)$ & $(2)$ & $(3)$ & $(4)$ & $(5)$ & $(6)$ \\
\hline Treat $\times$ Post & $0.035^{* * *}$ & $-0.007^{* * *}$ & $0.029^{* * *}$ & $0.035^{* * *}$ & $-0.006^{* * *}$ & $0.029^{* * *}$ \\
& $(3.150)$ & $(-3.336)$ & $(2.632)$ & $(3.096)$ & $(-3.080)$ & $(2.633)$ \\
$F M$ & & & & $0.009^{*}$ & $0.003^{* * *}$ & -0.000 \\
& & & & $(1.859)$ & $(3.750)$ & $(-0.020)$ \\
Treat $\times$ Post $\times F M$ & & & & 0.007 & $-0.006^{* * *}$ & 0.001 \\
& & & & $(0.843)$ & $(-3.773)$ & $(0.168)$ \\
DF & & & $-0.894 * * *$ & & & $-0.953^{* * *}$ \\
& & & $(-19.098)$ & & & $(-19.749)$ \\
DF $\times$ FM & & & & & & $0.228^{* * *}$ \\
& & & & & & $(4.801)$ \\
Constant & $-5.690^{* * * *}$ & $-0.518^{* * *}$ & $-6.153^{* * *}$ & $-5.673 * * *$ & $-0.516^{* * *}$ & $-6.144 * * *$ \\
& $(-42.245)$ & $(-20.724)$ & $(-45.570)$ & $(-42.075)$ & $(-20.616)$ & $(-45.503)$ \\
\hline
\end{tabular}




\begin{tabular}{lcccccc}
\hline Control variables & Yes & Yes & Yes & Yes & Yes & Yes \\
$\mathrm{N}$ & 15,024 & 15,024 & 15,024 & 15,024 & 15,024 & 15,024 \\
$\mathrm{R}^{2}$ & 0.746 & 0.204 & 0.753 & 0.746 & 0.205 & 0.753 \\
\hline
\end{tabular}

277 Note: t-statistics in parentheses; $* * * \mathrm{p}<0.01, * * \mathrm{p}<0.05, * \mathrm{p}<0.1$.

\subsection{Heterogeneity test for different groups at the regional level}

According to the criterion formulated by the National Bureau of Statistics in Chinese mainland, we have divided the full sample into three regions including the eastern, central, and western region, and reported the empirical results of them in Table 4, Table 5, and Table 6, respectively.

The empirical results for the eastern sample are reported in the Table 4. Column (1) shows that green credit policy has significantly positive effect on total factor productivity, indicating that green credit policy promotes total factor productivity of the polluting enterprises, that is, $\mathrm{H} 1$ is supported for the eastern sample. Column (2) shows that green credit policy has insignificantly negative effect on debt financing, indicating that green credit policy fails to reduce debt financing of the polluting enterprises, that is, $\mathrm{H} 2$ is not supported for the eastern sample. Column (3) shows that debt financing has significantly negative effect on total factor productivity, while the mediating effect of debt financing on the nexus between green credit policy and total factor productivity is not established, that is, H3 is not supported for the eastern sample. Column (4) shows that financial mismatch has failed to moderate the positive effect of green credit policy on total factor productivity, that is, H4 is not supported for the eastern sample. Columns (5) and (6) show that financial mismatch has enhanced the positive impact of green credit policy on total factor productivity via codirectionally moderating the negative impact of green credit policy on debt financing, but failed to weaken the positive impact of green credit policy on total factor productivity via oppositely moderating the negative impact of debt financing on total factor productivity, that is, H5 is supported while H6 is not supported for the eastern sample.

\section{Table 4}

Empirical results for the eastern sample.

\begin{tabular}{lcccccc}
\hline Variables & $T F P$ & $D F$ & $T F P$ & $T F P$ & $D F$ & $T F P$ \\
\cline { 2 - 7 } & $(1)$ & $(2)$ & $(3)$ & $(4)$ & $(5)$ & $(6)$ \\
\hline Treat $\times$ Post & $0.048^{* * *}$ & -0.003 & $0.045^{* * *}$ & $0.048^{* * * *}$ & -0.003 & $0.046^{* * * *}$ \\
& $(3.429)$ & $(-1.192)$ & $(3.278)$ & $(3.419)$ & $(-1.038)$ & $(3.328)$ \\
$F M$ & & & & 0.008 & $0.003 * * *$ & 0.003 \\
\hline
\end{tabular}




\begin{tabular}{|c|c|c|c|c|c|c|}
\hline & & & & $(1.523)$ & $(3.398)$ & $(0.570)$ \\
\hline \multirow[t]{2}{*}{ Treat $\times$ Post $\times F M$} & & & & 0.003 & $-0.006 * * *$ & -0.002 \\
\hline & & & & $(0.315)$ & $(-3.107)$ & $(-0.154)$ \\
\hline \multirow[t]{2}{*}{$D F$} & & & $-0.877 * * *$ & & & $-0.930 * * *$ \\
\hline & & & $(-15.461)$ & & & $(-15.698)$ \\
\hline \multirow[t]{2}{*}{$D F \times F M$} & & & & & & $0.165^{* * *}$ \\
\hline & & & & & & $(2.905)$ \\
\hline \multirow[t]{2}{*}{ Constant } & $-5.668 * * *$ & $-0.525^{* * *}$ & $-6.128 * * *$ & $-5.650 * * *$ & $-0.519 * * *$ & $-6.115^{* * *}$ \\
\hline & $(-34.379)$ & $(-17.053)$ & $(-37.061)$ & $(-34.205)$ & $(-16.838)$ & $(-36.937)$ \\
\hline Control variables & Yes & Yes & Yes & Yes & Yes & Yes \\
\hline $\mathrm{N}$ & 10,265 & 10,265 & 10,265 & 10,265 & 10,265 & 10,265 \\
\hline $\mathrm{R}^{2}$ & 0.749 & 0.217 & 0.756 & 0.749 & 0.218 & 0.756 \\
\hline
\end{tabular}

Note: t-statistics in parentheses; $* * * \mathrm{p}<0.01, * * \mathrm{p}<0.05, * \mathrm{p}<0.1$.

The empirical results for the central sample are reported in the Table 5. Column (1) shows

319 Empirical results for the central sample.

\begin{tabular}{lcccccc}
\hline Variables & $T F P$ & $D F$ & $T F P$ & $T F P$ & $D F$ & $T F P$ \\
\cline { 2 - 7 } & $(1)$ & $(2)$ & $(3)$ & $(4)$ & $(5)$ & $(6)$ \\
\hline Treat $\times$ Post & 0.006 & $-0.019^{* * *}$ & -0.005 & 0.008 & $-0.018^{* * * *}$ & -0.003 \\
\hline
\end{tabular}




\begin{tabular}{lcccccc}
\hline & $(0.252)$ & $(-3.959)$ & $(-0.220)$ & $(0.341)$ & $(-3.817)$ & $(-0.105)$ \\
$F M$ & & & & 0.001 & $0.006 * *$ & 0.009 \\
Treat $\times$ Post $\times F M$ & & & & $(0.125)$ & $(2.556)$ & $(0.733)$ \\
& & & & -0.015 & -0.004 & -0.016 \\
$D F$ & & & & $(-0.805)$ & $(-1.026)$ & $(-0.880)$ \\
& & & $-0.599 * * *$ & & & $-0.582 * * *$ \\
$D F \times F M$ & & & $(-5.714)$ & & & $(-5.398)$ \\
& & & & & & -0.083 \\
Constant & $-5.015 * * *$ & $-0.425^{* * *}$ & $-5.270^{* * *}$ & $-5.044 * * *$ & $-0.423 * * *$ & $-5.293 * * *$ \\
& $(-15.045)$ & $(-6.411)$ & $(-15.776)$ & $(-15.051)$ & $(-6.359)$ & $(-15.759)$ \\
Control variables & Yes & Yes & Yes & Yes & Yes & Yes \\
$\mathrm{N}$ & 2,624 & 2,624 & 2,624 & 2,624 & 2,624 & 2,624 \\
$\mathrm{R}^{2}$ & 0.732 & 0.134 & 0.736 & 0.732 & 0.136 & 0.736 \\
\hline
\end{tabular}

Note: $\mathrm{t}$-statistics in parentheses; $* * * \mathrm{p}<0.01, * * \mathrm{p}<0.05, * \mathrm{p}<0.1$.

321 The empirical results for the western sample are reported in the Table 6. Column (1) shows

322 that green credit policy has insignificantly positive effect on total factor productivity, indicating

323 that green credit policy fails to promote total factor productivity of the polluting enterprises, that is,

$324 \mathrm{H} 1$ is not supported for the western sample. Column (2) shows that green credit policy has

325 insignificantly negative effect on debt financing, indicating that green credit policy reduces debt

326 financing of the polluting enterprises, that is, $\mathrm{H} 2$ is not supported for the western sample. Column

327 (3) shows that debt financing has insignificantly negative effect on total factor productivity, the mediating effect of debt financing on the nexus between green credit policy and total factor productivity is not established, that is, H3 is not supported for the central sample. Column (4) shows that financial mismatch has failed to moderate the positive effect of green credit policy on total factor productivity, that is, H4 is not supported for the western sample. Columns (5) and (6) show that financial mismatch has not only failed to enhance the positive impact of green credit policy on total factor productivity via codirectionally moderating the negative impact of green credit policy on debt financing, but also failed to weaken the positive impact of green credit policy on total factor productivity via oppositely moderating the negative impact of debt financing on total factor productivity, that is, both $\mathrm{H} 5$ and $\mathrm{H} 6$ are not supported for the western sample.

\section{Table 6}

338 Empirical results for the western sample.

\begin{tabular}{lllllll}
\hline Variables & $T F P$ & $D F$ & $T F P$ & $T F P$ & $D F$ & $T F P$ \\
\hline
\end{tabular}




\begin{tabular}{lcccccc}
\hline & $(1)$ & $(2)$ & $(3)$ & $(4)$ & $(5)$ & $(6)$ \\
\hline Treat $\times$ Post & 0.010 & -0.004 & 0.005 & 0.005 & -0.003 & -0.001 \\
& $(0.318)$ & $(-0.702)$ & $(0.177)$ & $(0.170)$ & $(-0.617)$ & $(-0.021)$ \\
$F M$ & & & & 0.009 & 0.000 & $-0.038^{* *}$ \\
& & & & $(0.595)$ & $(0.130)$ & $(-2.161)$ \\
Treat $\times$ Post $\times F M$ & & & & $0.058^{* *}$ & -0.006 & $0.057 * *$ \\
& & & & $(2.377)$ & $(-1.266)$ & $(2.400)$ \\
$D F$ & & & $-1.149 * * *$ & & & $-1.213^{* * *}$ \\
& & & $(-9.061)$ & & & $(-9.571)$ \\
$D F \times$ FM & & & & & & $0.644 * * *$ \\
& & & & & & $(4.975)$ \\
Constant & $-4.779 * * *$ & $-0.443 * * *$ & $-5.288^{* * *}$ & $-4.756 * * *$ & $-0.444 * * *$ & $-5.339 * * *$ \\
& $(-11.485)$ & $(-5.935)$ & $(-12.863)$ & $(-11.447)$ & $(-5.934)$ & $(-13.074)$ \\
Control variables & Yes & Yes & Yes & Yes & Yes & Yes \\
$\mathrm{N}$ & 2,135 & 2,135 & 2,135 & 2,135 & 2,135 & 2,135 \\
$\mathrm{R}^{2}$ & 0.665 & 0.225 & 0.680 & 0.667 & 0.226 & 0.685 \\
\hline
\end{tabular}

Note: $\mathrm{t}$-statistics in parentheses; $* * * \mathrm{p}<0.01, * * \mathrm{p}<0.05, * \mathrm{p}<0.1$.

\subsection{Heterogeneity test for different groups at the property rights level}

According to the heterogeneity of enterprises at the property rights level, we have largely divided the full sample into two groups including the state-owned and non-state-owned enterprises, and reported the empirical results of them in Table 7 and Table 8, respectively.

The empirical results for the state-owned sample are reported in the Table 7. Column (1) shows that green credit policy has significantly positive effect on total factor productivity, indicating that green credit policy promotes total factor productivity of the polluting enterprises, that is, $\mathrm{H} 1$ is supported for the state-owned sample. Column (2) shows that green credit policy has significantly negative effect on debt financing, indicating that green credit policy reduces debt financing of the polluting enterprises, that is, $\mathrm{H} 2$ is supported for the state-owned sample. Column

350 (3) shows that debt financing has significantly negative effect on total factor productivity, 351 indicating that debt financing has partly and positively mediated the nexus between green credit 352 policy and total factor productivity, that is, H3 is supported for the state-owned sample. Column (4) 353 shows that financial mismatch has failed to moderate the positive effect of green credit policy on 354 total factor productivity, that is, H4 is not supported for the state-owned sample. Columns (5) and 355 (6) show that financial mismatch has not only enhanced the positive impact of green credit policy on total factor productivity via codirectionally moderating the negative impact of green credit policy on debt financing, but also weakened the positive impact of green credit policy on total 

productivity, that is, both H5 and H6 are supported for the state-owned sample.

Table 7

361 Empirical results for the state-owned sample.

\begin{tabular}{lcccccc}
\hline Variables & $T F P$ & $D F$ & $T F P$ & $T F P$ & $D F$ & $T F P$ \\
\cline { 2 - 7 } & $(1)$ & $(2)$ & $(3)$ & $(4)$ & $(5)$ & $(6)$ \\
\hline Treat $\times$ Post & $0.050^{* * *}$ & $-0.016^{* * *}$ & $0.035^{* * *}$ & $0.048^{* * *}$ & $-0.016^{* * *}$ & $0.033^{* *}$ \\
& $(3.133)$ & $(-5.070)$ & $(2.194)$ & $(3.014)$ & $(-4.841)$ & $(2.093)$ \\
$F M$ & & & & $0.026^{* * *}$ & 0.001 & 0.013 \\
& & & & $(3.102)$ & $(0.489)$ & $(1.329)$ \\
Treat $\times$ Post $\times$ FM & & & & 0.004 & $-0.012^{* * *}$ & -0.009 \\
& & & & $(0.247)$ & $(-3.745)$ & $(-0.570)$ \\
DF & & & $-0.951^{* * *}$ & & & $-0.980^{* * *}$ \\
& & & $(-13.061)$ & & & $(-13.316)$ \\
DF $\times$ FM & & & & & & $0.229^{* * *}$ \\
& & & & & & $(2.913)$ \\
Constant & $-5.920^{* * * *}$ & $-0.430^{* * *}$ & $-6.329 * * *$ & $-5.912^{* * *}$ & $-0.435^{* * *}$ & $-6.333^{* * *}$ \\
& $(-25.273)$ & $(-9.085)$ & $(-27.274)$ & $(-25.258)$ & $(-9.204)$ & $(-27.323)$ \\
Control variables & Yes & Yes & Yes & Yes & Yes & Yes \\
$\mathrm{N}$ & 4,992 & 4,992 & 4,992 & 4,992 & 4,992 & 4,992 \\
$\mathrm{R}^{2}$ & 0.744 & 0.172 & 0.753 & 0.744 & 0.175 & 0.754 \\
\hline
\end{tabular}

Note: t-statistics in parentheses; $* * * \mathrm{p}<0.01$, ** $\mathrm{p}<0.05, * \mathrm{p}<0.1$.

The empirical results for the non-state-owned sample are reported in the Table 8. Column (1) shows that green credit policy has significantly positive effect on total factor productivity, indicating that green credit policy promotes total factor productivity of the polluting enterprises, that is, H1 is supported for the non-state-owned sample. Column (2) shows that green credit policy has insignificantly positive effect on debt financing, indicating that green credit policy fails to reduce debt financing of the polluting enterprises, that is, $\mathrm{H} 2$ is not supported for the non-state-owned sample. Column (3) shows that debt financing has significantly negative effect on total factor productivity, while the mediating effect of debt financing on the nexus between green credit policy and total factor productivity is not established, that is, H3 is not supported for the non-state-owned sample. Column (4) shows that financial mismatch has failed to moderate the positive effect of green credit policy on total factor productivity, that is, H4 is not supported for the non-state-owned sample. Columns (5) and (6) show that financial mismatch has only enhanced the positive impact of green credit policy on total factor productivity via codirectionally 
moderating the negative impact of green credit policy on debt financing, but failed to weaken the positive impact of green credit policy on total factor productivity via oppositely moderating the negative impact of debt financing on total factor productivity, that is, H5 is supported while H6 is not supported for the non-state-owned sample.

Table 8

Empirical results for the non-state-owned sample.

\begin{tabular}{lcccccc}
\hline Variables & $T F P$ & $D F$ & $T F P$ & $T F P$ & $D F$ & $T F P$ \\
\cline { 2 - 7 } & $(1)$ & $(2)$ & $(3)$ & $(4)$ & $(5)$ & $(6)$ \\
\hline Treat $\times$ Post & $0.028^{*}$ & 0.001 & $0.028^{*}$ & $0.027^{*}$ & 0.002 & $0.029^{*}$ \\
& $(1.738)$ & $(0.318)$ & $(1.807)$ & $(1.684)$ & $(0.598)$ & $(1.851)$ \\
$F M$ & & & & 0.001 & $0.004 * * *$ & -0.004 \\
& & & & $(0.155)$ & $(4.306)$ & $(-0.599)$ \\
Treat $\times$ Post $\times$ FM & & & & 0.009 & $-0.004 * *$ & 0.006 \\
& & & & $(0.895)$ & $(-2.294)$ & $(0.549)$ \\
DF & & & $-0.855^{* * *}$ & & & $-0.918^{* * *}$ \\
& & & $(-13.976)$ & & & $(-14.226)$ \\
DF $\times$ FM & & & & & & $0.179 * * *$ \\
& & & & & & $(2.983)$ \\
Constant & $-5.554^{* * *}$ & $-0.527 * * *$ & $-6.005^{* * *}$ & $-5.548^{* * *}$ & $-0.518^{* * *}$ & $-6.001 * * *$ \\
& $(-33.015)$ & $(-17.716)$ & $(-35.445)$ & $(-32.887)$ & $(-17.402)$ & $(-35.361)$ \\
Control variables & Yes & Yes & Yes & Yes & Yes & Yes \\
$\mathrm{N}$ & 10,032 & 10,032 & 10,032 & 10,032 & 10,032 & 10,032 \\
$\mathrm{R}^{2}$ & 0.750 & 0.235 & 0.756 & 0.750 & 0.237 & 0.756 \\
\hline
\end{tabular}

Note: t-statistics in parentheses; $* * * \mathrm{p}<0.01, * * \mathrm{p}<0.05, * \mathrm{p}<0.1$.

\section{Conclusions, policy implications, and research prospects}

\subsection{Conclusions}

By using the mediated moderation model, taking the polluting enterprises as the treatment group and the other enterprises as the control group, this study has analyzed the impact of green credit policy on total factor productivity at the corporate level in China from the perspective of financial resource allocation, with the consideration of both the mediating role of debt financing and the moderating role of financial mismatch. The conclusions of this study are as follows:

Firstly, green credit policy has effectively and directly promoted total factor productivity at the corporate level in China, and this impact is transmitted partly through the intermediary of debt financing. Moreover, financial mismatch has enhanced this impact via codirectionally moderating the negative impact of green credit policy on debt financing, and weakened this impact via 
oppositely moderating the negative impact of debt financing on total factor productivity.

Secondly, the heterogeneity of green credit policy affecting total factor productivity is established at the regional level. Different from the less developed central and western regions, green credit policy has effectively and directly promoted total factor productivity at the corporate level in the eastern region. However, the mediating role of debt financing is not supported at the regional level. In addition, the moderating role of financial mismatch is merely established via codirectionally moderating the negative impact of green credit policy on debt financing in the eastern region.

Thirdly, green credit policy has effectively and directly promoted total factor productivity of both the state-owned and non-state-owned enterprises, while the difference of the influencing intensity between those two groups also verifies the non-state-owned enterprises' dilemma of difficult and expensive debt financing. In addition, the mediating role of debt financing is merely established for the state-owned enterprises. Furthermore, the moderating role of financial mismatch is established via codirectionally moderating the negative impact of green credit policy on debt financing for the state-owned enterprises, and via oppositely moderating the negative impact of debt financing on total factor productivity for both the state-owned and non-state-owned enterprises.

\subsection{Policy implications}

Based on the above conclusions of this study, as well as the practice of green credit policy and enterprise management in China, the following policy implications are provided.

Firstly, to adequately enjoy the positive impact of green credit policy on total factor productivity, the government should attach importance to the dual role of green financial products in economic development and environmental protection, increase investment in green financial infrastructure, expand the scope of pilot areas for green credit reform, design green incentive measures including interest discount, targeted rate cuts, and re-loans, and guide the enterprises to comply with the green principles.

Secondly, considering the intermediary role of debt financing, it is important and necessary to clarify the influencing mechanism of green credit policy on total factor productivity at the corporate level, to obtain timely feedback from enterprises and to adjust the intensity of green credit policy. In addition, to enjoy the bonus of green credit policy, the heterogeneous impacts of 
green credit policy should be paid more attention, more preferential measures should be given to the central and western enterprises, and the non-state-owned enterprises.

Thirdly, to reduce the dilution effect of financial mismatch on the positive nexus between green credit policy and total factor productivity, it is also important and necessary to deepen the financial supply-side structural reform, and make full use of big data to realize the tripartite information sharing among the government, banks, and enterprises, which is also conducive to optimize the financial and investment environment for promoting the follow-up development of green credit policy.

\subsection{Research prospects}

Since this study has comprehensively investigated the influencing mechanism of green credit policy on total factor productivity at the corporate level in China, some limitations should be identified to highlight the potential research directions. For instance, due to the constraint of data availability, our sample is based on the panel data of A-share listed enterprises, whether the mediated moderation route is supported for the unlisted enterprises still remains unclear. In addition, except for the mediating role of debt financing and the moderating role of financial mismatch, the other potential channels such as technical innovation and resource allocation on the nexus between green credit policy and total factor productivity also deserve an in-depth research in the future.

Ethics approval and consent to participate: Not applicable.

Consent for publication: Not applicable.

Authors Contributions: Yanchao Feng: Conceptualization, Methodology, Writing - Original draft; Qiong Shen: Writing- Reviewing and Editing.

Funding information: Sponsored by Program for Science\&Technology Innovation Talents in Universities of Henan Province (Grant No. 2021-CX-018) and Great Education Science Bidding Project of $14^{\text {th }}$ Five Year Plan in 2022 of Henan Province (Grant No. 2021JKZB05).

Conflicts of Interest: The authors declare that they have no competing interests.

Data Availability: The data used to support the findings of this study are available from the corresponding author upon request.

\section{References}

Cao, Y.W., Zhang, Y.T., Yang, L., Li, R.Y.M., Crabbe, M.J.C., 2021. Green Credit Policy and 
Maturity Mismatch Risk in Polluting and Non-Polluting Companies. Sustainability 13(7), 3615.

Han, Z.X., Xu, H.F., Tu, K.J., 2019. Research on the Effectiveness of Green Credit Policy -Based on The Empirical Study of 19 Listed Banks in China. 2019 3rd International Conference on Data Science and Business Analytics (Icdsba 2019), 202-205.

Hu, G.Q., Wang, X.Q., Wang, Y., 2021. Can the green credit policy stimulate green innovation in heavily polluting enterprises? Evidence from a quasi-natural experiment in China. Energ. Econ. 98, 105134.

Kang, H., Jung, S.Y., Lee, H., 2020. The impact of Green Credit Policy on manufacturers' efforts to reduce suppliers' pollution. J. Clean. Prod. 248, 119271.

Karabarbounis, M., Macnamara, P., 2021. Misallocation and financial frictions: The role of long-term financing. Rev. Econ. Dynam. 40, 44-63.

Levinsohn, J., Petrin, A., 2003. Estimating production functions using inputs to control for unobservables. Rev. Econ. Stud. 70(2), 317-341.

Ling, S.X., Han, G.S., An, D., Hunter, W.C., Li, H., 2020. The Impact of Green Credit Policy on Technological Innovation of Firms in Pollution-Intensive Industries: Evidence from China. Sustainability 12(11), 4493.

Liu, J.Y., Xia, Y., Fan, Y., Lin, S.M., Wu, J., 2017. Assessment of a green credit policy aimed at energy-intensive industries in China based on a financial CGE model. J. Clean. Prod. 163, 293-302.

Liu, X.H., Wang, E.X., Cai, D.T., 2019. Green credit policy, property rights and debt financing: Quasi-natural experimental evidence from China. Financ. Res. Lett. 29, 129-135.

Moll, B., 2014. Productivity Losses from Financial Frictions: Can Self-Financing Undo Capital Misallocation? Am. Econ. Rev. 104(10), 3186-3221.

Song, M.L., Xie, Q.J., Shen, Z.Y., 2021. Impact of green credit on high-efficiency utilization of energy in China considering environmental constraints. Energ. Policy 153, 112267.

Sun, J.X., Wang, F., Yin, H.T., Zhang, B., 2019. Money Talks: The Environmental Impact of China's Green Credit Policy. J. Policy Anal. Manag. 38(3), 653-680.

Uras, B.R., 2014. Corporate financial structure, misallocation and total factor productivity. J. Bank. Financ. 39, 177-191. 
Wang, F., Yang, S.Y., Reisner, A., Liu, N., 2019. Does Green Credit Policy Work in China? The Correlation between Green Credit and Corporate Environmental Information Disclosure Quality. Sustainability 11(3), 733.

Wang, K., Zhao, R.Q., Chen, H.R., 2018. Optimal credit period and green consumption policies with cash-credit payments under asymmetric information. J. Clean. Prod. 205, 706-720.

Wang, Y.L., Lei, X.D., Zhao, D.X., Long, R.Y., Wu, M.F., 2021. The Dual Impacts of Green Credit on Economy and Environment: Evidence from China. Sustainability 13(8), 4574.

Wen, H.W., Lee, C.C., Zhou, F.X., 2021. Green credit policy, credit allocation efficiency and upgrade of energy-intensive enterprises. Energ. Econ. 94, 105099.

Wu, G.L., 2018. Capital misallocation in China: Financial frictions or policy distortions? J. Dev. Econ. 130, 203-223.

Xing, C., Zhang, Y.M., Wang, Y., 2020. Do Banks Value Green Management in China? The Perspective of the Green Credit Policy. Financ. Res. Lett. 35, 101601.

Xu, X.K., Li, J.S., 2020. Asymmetric impacts of the policy and development of green credit on the debt financing cost and maturity of different types of enterprises in China. J. Clean. Prod. 264, 121574.

Zhang, B., Yang, Y., Bi, J., 2011. Tracking the implementation of green credit policy in China: Top-down perspective and bottom-up reform. Journal of Environmental Management 92(4), 1321-1327.

Zhou, G.Y., Liu, C., Luo, S.M., 2021. Resource Allocation Effect of Green Credit Policy: Based on DID Model. Mathematics 9(2), 159. 